\title{
Calcareous seaweed flour in the diet of Japanese quails and its effects on egg conservation
}

Farinha de alga calcária na dieta de codornas japonesas e seus efeitos na conservação de ovos

${ }^{1}$ SPANIVELLO, Gabrielly Ribeiro https://orcid.org/0000-0002-0092-0232

${ }^{1}$ VALENTIM, Jean kaique

https://orcid.org/0000-0001-8547-4149

${ }^{1}$ GARCIA, Rodrigo Garófallo

https://orcid.org/0000-0002-4978-9386

${ }^{1}$ BURBARELLI, Maria Fernanda de Castro https://orcid.org/0000-0002-8079-2890
${ }^{1}$ PRZYBULINSKI, Bruna Barreto https://orcid.org/0000-0002-4967-5899

${ }^{1}$ KOMIYAMA, Claudia Marie

https://orcid.org/0000-0001-8732-5745

${ }^{2}$ EBERHART, Bruna de Souza

https://orcid.org/0000-0001-8111-8729

${ }^{1}$ CASTILHO, Vivian Aparecida Rios de https://orcid.org/0000-0001-7895-1314

${ }^{1}$ Universidade Federal da Grande Dourados - UFGD, Rua João Rosa Góes, no 1761, Vila Progresso, Dourados/ MS, CEP: 79825-070, Brasil

${ }^{2}$ Centro Universitário da Grande Dourados - Unigran, Rua Balbina de Matos, 2121 - Jd. Universitário CEP: 79.824-900 - Dourados/MS, Brasil

*Mail for correspondence: kaique.tim@ @otmail.com

\section{ABSTRACT}

The aim of this study is to evaluate the influence of including levels of calcareous seaweed flour in replacement for calcite limestone on the diet under egg conservation at different storage periods. 140 Japanese quails were used in a completely randomized experiment consisting of a $4 \times 4$ factorial design. The factorial design was four inclusions of calcareous seaweed $(0 \%, 10 \%, 20 \%$, and 30\%) and four storage periods (zero, seven, 14, and 21 days) with ten replications of three eggs each. The egg quality variables were evaluated. Data were subjected to analysis of variance using Tukey test and polynomial regression at a 5\% significance level. There was no interaction effect between the factor's storage time and inclusion of calcareous seaweed $(\mathrm{p}>0.05)$. There was an increasing linear effect on shell weight and thickness in relation to inclusion levels of calcareous seaweed. There was an individual effect of egg storage time ( $>>0.05)$ on egg weight, yolk color, albumen and yolk height, yolk weight and percentage, albumen, yolk index, yolk diameter, specific gravity, and Haugh unit. The inclusion of up to $30 \%$ of calcareous seaweed in replacement for calcite limestone in the diet of Japanese quails improves the weight and thickness of eggshells but does not influence the conservation of the eggs up to 21 days of storage. Keywords: storage, quail farming, conservation, shell thickness, organic minerals.

\section{RESUMO}


O objetivo deste estudo foi avaliar a influência da inclusão de níveis de farinha de alga calcária em substituição ao calcário calcítico na dieta sob a conservação de ovos em diferentes períodos de armazenamento. Foram utilizadas 140 codornas japonesas em um delineamento inteiramente casualizado composto por um fatorial $4 \times 4$. Sendo 4 inclusões de alga calcária $(0 \%, 10 \%, 20 \%$ e $30 \%)$ e 4 períodos de armazenamento $(0,7,14$ e 21 dias $)$ com dez repetições de três ovos em cada. Foram avaliadas as variáveis de qualidade de ovos das aves. Os dados foram submetidos a análise de variância utilizando o teste de Tukey e regressão polinomial ao nível de 5\% de significância. Não houve efeito da interação entre os fatores tempo de armazenamento e inclusão de alga calcárea ( $p>0,05)$. Houve efeito linear crescente no peso e espessura da casca em relação aos níveis de inclusão de alga calcárea. Houve efeito individual do tempo de armazenamento dos ovos (p>0,05) sobre parâmetros peso de ovo, coloração da gema, altura de albúmen e gema, peso e porcentagem da gema, albúmen, índice de gema, diâmetro de gema, gravidade especifica e unidade Haugh. A inclusão de até $30 \%$ de alga calcária em substituição ao calcário calcítico na dieta codornas japonesas aprimora o peso e a espessura da casca do ovo, mas não influencia na conservação dos ovos até 21 dias de armazenamento.

Palavras-chaves: armazenamento, coturnicultura, conservação, espessura da casca, minerais orgânicos.

\section{INTRODUCTION}

Quail farming is considered an alternative activity for small producers due to its low initial investment, use of small areas, and low labor (BITTENCOURT et al., 2019; VALENTIM et al., 2019). However, over the years, this activity has grown and has ensured good returns to rural producers (FERNANDES et al., 2018; FERRONATO et al., 2020).

Among the difficulties found in the production of quails, we can mention the quality of eggs, most notably the quality of shells, which is affected by bird age, bird nutrition, and heat stress (SILVA et al., 2018). It is possible to evaluate this parameter in the field, where shell thickness, shell percentage and shell weight are measured (LEMOS et al., 2017).

The shell quality is also directly related to storage in the case of unrefrigerated eggs kept at room temperature because of the porosity of the shell. Through evaporation, shells lose $\mathrm{CO}_{2}$ and water to the environment, reducing egg weight (HENRIQUES et al., 2018). To maintain egg integrity, it is recommended that soon after the procedures on the farm the eggs be stored in a refrigeration system (CARVALHO et al., 2003). However, often the logistics of conservation and transport of eggs do not allow for a quick storage process.

In order to reduce egg losses due to shell quality and integrity, calcareous seaweed flour is used. It is considered a mineral linked to an organic molecule. Marine algae calcareae have a high content of mineral elements from the marine environment, in addition to a high amount of nutritive substances (ARAÚJO et al., 2020).

Algae calcareae (Lithothamnium calcareum) is a source of macro- and microminerals at varying concentrations depending on the location, season, and depth they are found. They are a source 
of calcium and magnesium that acts as a substitute for calcite limestone (MELO et al., 2009). As Souza et al. (2015) reported, calcite mineral supplementation improves eggshell thickness and consequently breakage resistance, suggesting that eggs may have a longer shelf life.

The aim of this study is thus to evaluate the influence of including levels of calcareous seaweed flour in replacement for calcite limestone on the diet under egg conservation at different storage periods.

\section{MATHERIAL AND METHODS}

The experiment was conducted in the quail breeding sector of the Federal University of Grande Dourados. The procedures and handling of animals were conducted under the approval of the Ethics Committee on the Use of Animals (CEUA) of the University Center of Grande Dourados (Unigran/Dourados) under protocol CEUA no. 052/18. In the pre-experimental phase 140 Japanese quails (Coturnix coturnix japonica) with 200 days of age, average weight of $120 \mathrm{~g}$ and average laying rate of $85 \%$ were used.

The birds were housed in cages placed in lines arranged in parallel over five floors. The dimensions of cages were $25 \mathrm{~cm}$ width, $35 \mathrm{~cm}$ length, and $20 \mathrm{~cm}$ height, corresponding to an area of $175 \mathrm{~cm}^{2} / \mathrm{bird}$ housed. Feeders were of chute type and drinkers of nipple type. The algae calcareae were purchased from a trading company.

The feed used was formulated according to the requirements of Rostagno et al. (2011) (Table 1).

Table 1. Nutritional and diet composition provided to birds during the experimental period

\begin{tabular}{|c|c|c|c|c|}
\hline \multirow{2}{*}{ Ingredient $(\%)$} & \multicolumn{4}{|c|}{ Replacement percentage of algae calcareae $(\%)$} \\
\hline & 0 & 10 & 20 & 30 \\
\hline Ground corn & 54.17 & 54.17 & 54.17 & 54.17 \\
\hline Soybean meal & 34.7 & 34.7 & 34.7 & 34.7 \\
\hline Calcium carbonate & 7.01 & 6.309 & 5.608 & 4.907 \\
\hline Dicalcium phosphate & 1.15 & 1.15 & 1.15 & 1.15 \\
\hline Salt & 0.36 & 0.36 & 0.36 & 0.36 \\
\hline $\operatorname{Premix}^{1}$ & 1.5 & 1.5 & 1.5 & 1.5 \\
\hline Soy oil & 1.11 & 1.11 & 1.11 & 1.11 \\
\hline Algae calcareae & 0.00 & 0.701 & 1.402 & 2.103 \\
\hline Total & 100 & 100 & 100 & 100 \\
\hline
\end{tabular}

\begin{tabular}{lcccc}
\hline \multicolumn{5}{c}{ Calculated nutritional composition } \\
\hline GE $(\mathrm{Kcal} / \mathrm{Kg})$ & $2,800.00$ & $2,800.00$ & $2,800.00$ & $2,800.00$ \\
Crude protein $(\%)$ & 19.46 & 19.46 & 19.46 & 19.46 \\
Digestible lysine $(\%)$ & 1.080 & 1.080 & 1.080 & 1.080 \\
Methionine + Cystine & 0.94 & 0.94 & 0.94 & 0.94 \\
$(\%)$ & & & &
\end{tabular}




\begin{tabular}{lcccc} 
Digest. tryptophan (\%) & 0.23 & 0.23 & 0.23 & 0.23 \\
$\begin{array}{l}\text { Digest. Threonine (\%) } \\
\text { Calcium (\%) }\end{array}$ & 0.68 & 0.68 & 0.68 & 0.68 \\
$\begin{array}{l}\text { Available phosphorus } \\
(\%)\end{array}$ & 3.07 & 3.0617 & 3.053 & 3.045 \\
Sodium $(\%)$ & 0.30 & 0.30 & 0.30 & 0.30 \\
Crude fiber $(\%)$ & 0.16 & 0.16 & 0.16 & 0.16 \\
\hline
\end{tabular}

${ }^{1}$ Minimum levels per kg of premix: Folic Acid (min.) $900.0 \mathrm{mg}$; Pantothenic Acid (min.) 12,000.00 mg; Biotin (min.) 77.0 mg; Calcium (min. - max.) 130.0 - 143.7 g; Niacin (min.) 40,000.0 mg; Selenium (min.) $370.0 \mathrm{mg}$; Vitamin A (min.) 8,800,000.0 IU; Vitamin B1 (min.) 2,500.0 mg; growth vitamin $0.04 \mathrm{~g}$; antioxidant $0.02 \mathrm{~g}$; Mn $75 \mathrm{mg}$; Zn $50 \mathrm{mg}$; Cu $8 \mathrm{mg}$; I $0.75 \mathrm{mg}$; Fe $50 \mathrm{mg}$. Copper (min.) 7,0000.0 mg; iron (min.) $50.0 \mathrm{~g}$; iodine (min.) $1,500.0 \mathrm{mg}$; manganese (min.) $67.5 \mathrm{~g}$; zinc (min.) $45.6 \mathrm{~g}$.

Feed and water were provided ad libitum. Table 2 shows the chemical calcite limestone as reported by Dias et composition of algae calcareae and al. (2000).

Table 2. Chemical composition of algae calcareae and calcite limestone

\begin{tabular}{lcc}
\hline Chemical composition & Algae calcareae & Calcite limestone \\
\hline Ash $(\%)$ & 95.00 & 97.7 \\
Calcium (\%) & 32.39 & 39.9 \\
Magnesium (\%) & 5.00 & 0.32 \\
Sulfur (\%) & 0.25 & ----- \\
Sodium (\%) & 0.13 & ----- \\
Potassium (\%) & 0.01 & ----- \\
Chlorine (\%) & 0.10 & ----- \\
Phosphorus (\%) & 0.02 & ----- \\
Boron (ppm) & 10.00 & ---- \\
Iron (ppm) & 125.00 & 90.00 \\
Copper (ppm) & 725.00 & ----- \\
Zinc (ppm) & 5.50 & ----- \\
Manganese (ppm) & 10.00 & ----- \\
Molybdenum (ppm) & 2.50 & ----- \\
Selenium (ppm) & 0.50 & ----- \\
Iodine (ppm) & 6.00 & ----- \\
\hline
\end{tabular}

The experiment was completely randomized in a $4 \times 4$ factorial design with four diets $(0 \%, 10 \%, 20 \%$, and $30 \%)$ and four storage periods $(0,7,14$, and 21 days), with ten replications of three eggs each, totaling 480 eggs analyzed. Egg quality evaluations were conducted in a natural environment.
After two experimental periods of 28 days each, egg collections were conducted for egg storage, which was carried out in a room with natural ventilation, free from direct sunlight, in a dry and ventilated place, with a minimum and maximum temperature of $32.8^{\circ} \mathrm{C}$ and $21.9^{\circ} \mathrm{C}$, respectively, and 
maximum $\mathrm{RH}$ of $69 \%$ and minimum $\mathrm{RH}$ of $41.5 \%$.

\section{Eggs quality}

Eggs were stored according to treatment in order to subsequently perform egg quality analyses and obtain the following quality data: egg weight, egg specific gravity $\left(\mathrm{g} / \mathrm{cm}^{3}\right)$, colorimetry $\left(\mathrm{L}, \mathrm{a}^{*}, \mathrm{~b}^{*}\right)$, albumen and yolk height, yolk diameter $(\mathrm{mm})$, weight and percentage of albumen, shell and yolk (\%), shell thickness, Haugh unit, and yolk index as indicated by Bittencourt et al. (2019).

\section{Egg weight}

Eggs were identified according to treatment and individually weighed using a $0.01-\mathrm{g}$ precision semi-analytical scale.

\section{Specific gravity}

After weighing, eggs were sent to laboratory for specific gravity analysis. Buckets with different concentrations of saline solution $(\mathrm{NaCl})$ were used. Their densities were measured using a densimeter ranging from 1.065 to 1.100 , with intervals of 0.005 . The eggs were subjected from the lowest to the highest concentration. When they floated, their specific gravity was recorded.

\section{Yolk color}

After breaking the eggs, the yolk and albumen were separated from shells on a flat surface. The yolk color was evaluated using a portable color meter, model Minolta CR 410, which evaluates the parameters luminosity $\left(\mathrm{L}^{*}\right)$, red $\left(\mathrm{a}^{*}\right)$ and yellow $\left(b^{*}\right)$ at three different points on the yolk surface.

Yolk and albumen height and yolk diameter
The yolk and albumen height and the yolk diameter were measured using a caliper and a tripod. The yolk height was measured in the central region and albumen height was measured $4 \mathrm{~cm}$ from the yolk. This analysis was performed by only one person in order to provide greater data accuracy.

Weight and percentage of yolk, albumen and shell

The yolk was separated from the albumen to be individually weighed on the digital scale. The albumen weight was obtained by the difference between the egg and yolk weight, discounting the shell weight. The shell weight was obtained after washing and drying it in a natural environment for 24 hours. The percentage of shell, yolk and albumen was obtained by dividing these components by the egg weight, and this result was multiplied by 100 .

\section{Shell thickness}

After the shells were washed and dried, shell thickness was measured at three different points using a Digimess precision caliper of $0.001 \mathrm{~mm}$, calculating the means of these three thickness points.

\section{Haugh unit}

The Haugh Unit is the mathematical equation described by Stadelman and Cotteril (1986), which correlates egg weight with yolk or albumen height. The higher the HU, the better the egg quality.

$$
\begin{gathered}
U H=100 \log \{H+7,57-1,7 \\
\left.* W^{0,37}\right\}
\end{gathered}
$$

Where the variable $\mathrm{H}=$ dense albumen height $(\mathrm{mm})$ and $\mathrm{W}=$ egg weight $(\mathrm{g})$.

Yolk Index 
The yolk index was calculated by the relation between the height and diameter of the yolk.

\section{Statistical analysis}

Data were analyzed using the $\mathrm{R}$ Studio program (2012), and the normality of residues was verified using the Shapiro-Wilk test. The variances were compared using the Tukey test was used. In all analyses performed, the level of significance adopted was 5\%.

\section{RESULTS AND DISCUSSION}

There was no interaction between storage time and inclusion levels of algae calcareae
Levene test. Subsequently, the data were submitted to analysis of variance to verify whether there was an interaction effect between the factors of algae calcareae and storage time and their isolated effects. When analyzing the main effects, the contrasts of orthogonal polynomials were used and the regression equations were fitted for algae calcareae; for the effect of storage time, the for the variables egg weight, yolk weight, shell weight, albumen weight, and shell thickness, as Table 3 shows.

Table 3. Egg (g), yolk (g), albumen (g) and shell (g) weight, and shell thickness (mm) of Japanese quail eggs stored for different periods (zero, seven, 14, and 21 days) Japanese quail eggs stored for different period
fed on different algae calcareae inclusion levels

\begin{tabular}{|c|c|c|c|c|c|c|c|c|c|c|}
\hline \multirow[b]{2}{*}{ Variable } & \multirow{2}{*}{$\begin{array}{l}\text { Time } \\
\text { (days) }\end{array}$} & \multicolumn{4}{|c|}{ Inclusion levels of algae calcareae $(\%)$} & \multirow[b]{2}{*}{ Mean } & \multirow[b]{2}{*}{ MSE } & \multicolumn{3}{|c|}{ Probability } \\
\hline & & 0 & 10 & 20 & 30 & & & $\mathrm{~N}$ & $\begin{array}{l}\text { Time } \\
(\mathrm{T})\end{array}$ & $\mathrm{N}^{*} \mathrm{~T}$ \\
\hline \multirow{5}{*}{ Egg weight } & 0 & 11.788 & 12.154 & 11.270 & 11.830 & $11.761 \mathrm{~A}$ & \multirow{4}{*}{0.203} & \multirow{4}{*}{0.2105} & \multirow{4}{*}{$<0.001$} & \multirow{4}{*}{0.4971} \\
\hline & 7 & 11.895 & 11.954 & 11.510 & 11.598 & $11.739 \mathrm{~A}$ & & & & \\
\hline & 14 & 11.478 & 10.312 & 10.947 & 10.557 & $10.823 \mathrm{~B}$ & & & & \\
\hline & 21 & 11.055 & 10.158 & 10.092 & 11.002 & $10.577 \mathrm{~B}$ & & & & \\
\hline & & 11.554 & 11.145 & 10.955 & 11.247 & & & & & \\
\hline \multirow{6}{*}{$\begin{array}{c}\text { Yolk } \\
\text { weight }\end{array}$} & 0 & 3.559 & 3.685 & 3.563 & 3.487 & $3.573 \mathrm{~A}$ & \multirow{5}{*}{0.138} & \multirow{5}{*}{0.106} & \multirow{5}{*}{$<0.001$} & \multirow{5}{*}{0.1676} \\
\hline & 7 & 3.660 & 3.664 & 3.674 & 3.673 & $3.668 \mathrm{~A}$ & & & & \\
\hline & 14 & 3.519 & 2.883 & 3.248 & 2.727 & $3.094 \mathrm{~B}$ & & & & \\
\hline & & & 2.312 & 2.131 & 2.814 & $2.681 \mathrm{C}$ & & & & \\
\hline & 21 & 2.469 & & & & & & & & \\
\hline & Mean & 3.552 & 3.136 & 3.154 & 3.175 & & & & & \\
\hline \multirow{5}{*}{$\begin{array}{c}\text { Albumen } \\
\text { weight }\end{array}$} & 0 & 7.477 & 7.767 & 6.951 & 7.631 & 7.457 & \multirow{4}{*}{0.197} & \multirow{4}{*}{0.679} & \multirow{4}{*}{0.321} & \multirow{4}{*}{0.928} \\
\hline & 7 & 7.414 & 7.378 & 7.037 & 7.103 & 7.233 & & & & \\
\hline & 14 & 7.102 & 6.622 & 6.864 & 7.226 & 6.953 & & & & \\
\hline & 21 & 6.938 & 6.987 & 7.130 & 7.355 & 7.102 & & & & \\
\hline & Mean & 7.233 & 7.188 & 6.995 & 7.329 & & & & & \\
\hline \multirow{5}{*}{$\begin{array}{l}\text { Shell } \\
\text { weight }\end{array}$} & 0 & 0.750 & 0.777 & 0.777 & 0.764 & 0.767 & \multirow{4}{*}{0.016} & \multirow{4}{*}{$<0.001$} & \multirow{4}{*}{0.487} & \multirow{4}{*}{0.778} \\
\hline & 7 & 0.829 & 0.830 & 0.819 & 0.820 & 0.824 & & & & \\
\hline & 14 & 0.857 & 0.807 & 0.834 & 0.872 & 0.842 & & & & \\
\hline & 21 & 0.925 & 0.858 & 0.863 & 0.944 & 0.898 & & & & \\
\hline & Mean & 0.817 & 0.818 & 0.823 & 0.850 & & & & & \\
\hline \multirow{2}{*}{$\begin{array}{c}\text { Shell } \\
\text { thickness }\end{array}$} & 0 & 0.465 & 0.431 & 0.492 & 0.530 & 0.543 & \multirow[t]{2}{*}{0.009} & \multirow{2}{*}{0.001} & \multirow{2}{*}{0.0898} & \multirow{2}{*}{0.159} \\
\hline & 7 & 0.471 & 0.482 & 0.499 & 0.485 & 0.557 & & & & \\
\hline
\end{tabular}




\begin{tabular}{|c|c|c|c|c|c|c|}
\hline $\begin{array}{l}14 \\
21\end{array}$ & $\begin{array}{l}0.406 \\
0.363 \\
\end{array}$ & $\begin{array}{l}0.359 \\
0.338 \\
\end{array}$ & $\begin{array}{l}0.401 \\
0.367 \\
\end{array}$ & $\begin{array}{l}0.429 \\
0.366 \\
\end{array}$ & $\begin{array}{l}0.411 \\
0.400 \\
\end{array}$ & \\
\hline Mean & 0.403 & 0.426 & 0.440 & 0.453 & & \\
\hline Variable & \multicolumn{3}{|c|}{ Regression equation } & $\mathrm{R}^{2}$ & Effect & p-value \\
\hline Shell weight (g) & \multicolumn{3}{|c|}{$Y=0.6786 x+0.7982$} & 0.0982 & Linear & $\mathrm{P}>0.0001$ \\
\hline Shell thickness (mm) & \multicolumn{3}{|c|}{$Y=0.0544 x+0.4607$} & 0.0897 & Linear & $\mathrm{P}<0.0001$ \\
\hline
\end{tabular}

*MSE: Mean standard error. Means followed by different letters in columns differ statistically by Tukey test at $5 \%$ significance.

There was an effect of egg storage time on the variables egg weight and yolk weight $(p<0.05)$, obtaining higher values at times of zero and seven days compared to the times 14 and 21 days. There was an effect of the inclusion of algae calcareae on shell weight and thickness $(\mathrm{p}<0.05)$, and for the albumen weight there was no significant individual effect between the factors ( $p>0.05$ ).

There was an increasing linear effect for shell weight and thickness, that is, the greater the inclusion of algae, the greater the shell weight and thickness, indicating a greater calcium deposition by quails in eggs. The greater bioavailability of calcium from algae structures may have contributed to an increased shell thickness, as its binding with organic molecules facilitates its absorption, as reported by Carvalho et al. (2016).

According to Alvarenga et al. (2011), Lithothamnium can be used to replace sources of calcium. The calcium required for the formation of the shells comes exclusively from the diet. It is transported through the bloodstream as ionic calcium or bound to a phosphoprotein (CALDERANO et al.,
2010). Calcium is extremely important for the formation of eggshells. A single egg of a laying hen has about 3 grams of calcium, making an adequate supplementation of this mineral necessary for laying birds. As Lana et al. (2017) noted, the organic source of calcium was better assimilated by birds compared to the inorganic source.

The high bioavailability and solubility of algae calcareae components maximized egg quality mainly due to the increase in shell thickness and weight. Shell thickness is defined by the number of layers that make up its structure and has a direct influence on the internal preservation of eggs. The greater the shell thickness, the greater the resistance of the egg to environmental weathering related to handling, transport, and storage (SACCOMANI et al., 2019).

There was an effect of time on the percentage of yolk, shell and albumen $(\mathrm{p}<0.05)$ (Table 4). There was no effect of the interaction of factors and the inclusion of algae calcareae in isolation $(\mathrm{p}>0.05)$.

Table 4. Percentage of albumen, yolk, shell, and yolk shell diameter of Japanese quail eggs fed on algae calcareae and stored for four periods (zero, seven, 14, and 21 days)

\begin{tabular}{|c|c|c|c|c|c|c|c|c|c|c|}
\hline \multirow[b]{2}{*}{ Variable } & \multirow[b]{2}{*}{ Time } & \multicolumn{4}{|c|}{ Inclusion levels of algae calcareae (\%) } & \multirow[b]{2}{*}{ Mean } & \multirow[b]{2}{*}{ MSE } & \multicolumn{3}{|c|}{ Probability } \\
\hline & & 0 & 10 & 20 & 30 & & & $\mathrm{~N}$ & $\begin{array}{c}\text { Time } \\
(\mathrm{T})\end{array}$ & $\mathrm{N} * \mathrm{~T}$ \\
\hline & 0 & 30.315 & 30.419 & 31.676 & 29.582 & $30.498 \mathrm{~A}$ & 1.246 & 0.086 & 0.0003 & 0.1338 \\
\hline
\end{tabular}




\begin{tabular}{|c|c|c|c|c|c|c|c|c|c|c|}
\hline \multirow{3}{*}{$\begin{array}{c}\text { Egg yolk } \\
(\%)\end{array}$} & 7 & 30.781 & 30.667 & 31.934 & 31.748 & $31.282 \mathrm{~A}$ & & & & \\
\hline & 14 & 30.777 & 24.891 & 29.612 & 23.860 & $27.285 \mathrm{~B}$ & & & & \\
\hline & 21 & 31.995 & 20.902 & 20.064 & 24.589 & $24.387 \mathrm{C}$ & & & & \\
\hline & Mean & 30.967 & 26.720 & 28.321 & 27.445 & 28.363 & & & & \\
\hline \multirow{5}{*}{$\begin{array}{l}\text { Albumen } \\
(\%)\end{array}$} & 0 & 63.297 & 63.797 & 61.626 & 64.371 & $63.273 \mathrm{~A}$ & \multirow{4}{*}{1.960} & \multirow{4}{*}{0.973} & \multirow{4}{*}{$<0.0001$} & \multirow{4}{*}{0.0589} \\
\hline & 7 & 62.240 & 61.757 & 61.109 & 61.175 & $61.570 \mathrm{~A}$ & & & & \\
\hline & 14 & 56.600 & 41.664 & 52.615 & 48.764 & $47.411 \mathrm{~B}$ & & & & \\
\hline & 21 & 44.410 & 59.977 & 51.217 & 46.795 & $45.600 \mathrm{~B}$ & & & & \\
\hline & Mean & 56.637 & 56.799 & 56.642 & 57.776 & 56.963 & & & & \\
\hline \multirow{4}{*}{ Shell $(\%)$} & 0 & 6.387 & 6.448 & 6.879 & 6.513 & $6.557 \mathrm{C}$ & \multirow{4}{*}{0.071} & \multirow{4}{*}{0.578} & \multirow{4}{*}{$<0.0001$} & \multirow{4}{*}{0.7323} \\
\hline & 7 & 6.937 & 6.982 & 7.053 & 7.075 & 7.012 B & & & & \\
\hline & 14 & 7.505 & 6.954 & 7.632 & 7.379 & $7.367 \mathrm{~B}$ & & & & \\
\hline & 21 & 8.373 & 7.995 & 7.785 & 8.614 & $8.192 \mathrm{~A}$ & & & & \\
\hline & Mean & 7.301 & 7.095 & 7.337 & 7.395 & 7.282 & & & & \\
\hline
\end{tabular}

*MSE: Mean standard error. Means followed by different letters in columns differ statistically by Tukey test at $5 \%$ significance.

There was a decrease in the percentage of yolk and albumen and an increase in the percentage of shell over the time of storage. The egg loses water from the yolk and albumen; consequently, the percentage of shell is higher because the shell does not change over time, only in relation to the percentage with the other components. After laying, where there is an osmotic pressure gradient between the albumen and the yolk that increases progressively, as the water passes from the albumen to the yolk over time this factor intensifies at elevated temperatures (LANA et al., 2017).
These results reinforce those Barbosa et al. (2008) found. The authors also reported that the percentage of albumen decreases as the days go by due to the process described above together with the gas exchange between the egg and the environment. There was a decrease in specific gravity, albumen height, yolk height, HU, and yolk index and diameter according to the evaluated periods $(p<0.05)$. There was no effect of interaction and levels of algae calcareae in isolation on these variables (Table 5).

Table 5. Specific gravity, albumen $(\mathrm{cm})$ and yolk $(\mathrm{cm})$ height, Haugh Unit (UH), and yolk index $(\%)$ of Japanese quail eggs fed on different levels of algae calcareae inclusions and stored in four periods (zero, seven, 14, and 21 days)

\begin{tabular}{|c|c|c|c|c|c|c|c|c|c|c|}
\hline \multirow{2}{*}{ Variable } & \multirow{2}{*}{ Time } & \multicolumn{4}{|c|}{$\begin{array}{c}\% \text { of inclusion of calcareous } \\
\text { seaweed }\end{array}$} & \multirow{2}{*}{ Mean } & \multirow{2}{*}{ MSE } & \multicolumn{3}{|c|}{ Probability } \\
\hline & & 0 & 10 & 20 & 30 & & & $\mathrm{~N}$ & $\begin{array}{l}\text { Time } \\
(\mathrm{T})\end{array}$ & $\mathrm{N} * \mathrm{~T}$ \\
\hline \multirow{5}{*}{ Specific gravity } & 0 & 1.078 & 1.078 & 1.079 & 1.079 & $1.078 \mathrm{~A}$ & \multirow{4}{*}{0.04} & \multirow{4}{*}{0.9134} & \multirow{4}{*}{$<0.0001$} & \multirow{4}{*}{0.9146} \\
\hline & 7 & 1.068 & 1.069 & 1.068 & 1.067 & $1.068 \mathrm{~A}$ & & & & \\
\hline & 14 & 1.065 & 1.065 & 1.065 & 1.065 & $1.065 \mathrm{~B}$ & & & & \\
\hline & 21 & 1.065 & 1.065 & 1.065 & 1.065 & $1.065 \mathrm{~B}$ & & & & \\
\hline & Mean & 1.066 & 1.066 & 1.066 & 1.067 & & & & & \\
\hline
\end{tabular}




\begin{tabular}{|c|c|c|c|c|c|c|c|c|c|c|}
\hline \multirow{5}{*}{ Albumen height } & 0 & 4.441 & 4.947 & 4.632 & 4.157 & $4.544 \mathrm{~A}$ & \multirow{5}{*}{0.105} & \multirow{4}{*}{0.235} & \multirow{4}{*}{$<0.0001$} & \multirow{5}{*}{0.0589} \\
\hline & 7 & 4.092 & 4.869 & 4.418 & 4.850 & $4.557 \mathrm{~A}$ & & & & \\
\hline & 14 & 3.517 & 3.621 & 3.374 & 3.660 & $2.793 \mathrm{~B}$ & & & & \\
\hline & 21 & 3.165 & 3.857 & 3.005 & 3.085 & $3.528 \mathrm{~B}$ & & & & \\
\hline & Mean & 4.304 & 3.823 & 3.607 & 3.688 & & & & & \\
\hline \multirow{5}{*}{ Yolk height } & 0 & 11.037 & 11.161 & 10.242 & 10.724 & $10.791 \mathrm{~A}$ & \multirow{4}{*}{0.175} & \multirow{4}{*}{0.0658} & \multirow{4}{*}{$<0.0001$} & \multirow{4}{*}{0.0789} \\
\hline & 7 & 10.647 & 11.270 & 11.141 & 10.757 & $10.954 \mathrm{~A}$ & & & & \\
\hline & 14 & 6.320 & 4.829 & 6.301 & 5.001 & $5.613 \mathrm{~B}$ & & & & \\
\hline & 21 & 7.152 & 4.001 & 4.757 & 5.170 & $5.270 \mathrm{~B}$ & & & & \\
\hline & Mean & 8.789 & 7.815 & 8.110 & 7.913 & & & & & \\
\hline \multirow{5}{*}{$\mathrm{HU}$} & 0 & 88.703 & 91.245 & 81.456 & 87.073 & $89.280 \mathrm{~A}$ & \multirow{4}{*}{0.588} & \multirow{4}{*}{0.214} & \multirow{4}{*}{$<0.0001$} & \multirow{4}{*}{0.324} \\
\hline & 7 & 86.823 & 91.111 & 88.945 & 91.019 & $89.475 \mathrm{~A}$ & & & & \\
\hline & 14 & 83.741 & 80.769 & 76.259 & 79.803 & 80.143 B & & & & \\
\hline & 21 & 83.741 & 81.456 & 82.423 & 81.337 & $80.143 \mathrm{~B}$ & & & & \\
\hline & Mean & 88.143 & 86.145 & 84.432 & 84.808 & & & & & \\
\hline \multirow{5}{*}{ Yolk Index } & 0 & 0.280 & 0.270 & 0.276 & 0.294 & $0.280 \mathrm{~A}$ & \multirow{4}{*}{0.063} & \multirow{4}{*}{0.122} & \multirow{4}{*}{$<0.0001$} & \multirow{4}{*}{0.855} \\
\hline & 7 & 0.280 & 0.273 & 0.276 & 0.278 & $0.277 \mathrm{~A}$ & & & & \\
\hline & 14 & 0.215 & 0.160 & 0.217 & 0.182 & 0.193 B & & & & \\
\hline & 21 & 0.233 & 0.132 & 0.151 & 0.147 & $0.165 \mathrm{~B}$ & & & & \\
\hline & Mean & 0.252 & 0.239 & 0.230 & 0.225 & & & & & \\
\hline
\end{tabular}

MSE: Mean standard error. Means followed by different letters in columns differ statistically by Tukey test at $5 \%$ significance.

The specific gravity of eggs, according to Moura et al. (2020), is one of the most common techniques used to determine eggshell quality due to its speed, low cost, and practicality. The values of specific gravity in this research lowered gradually over time. Samli et al. (2005), Barbosa et al. (2008), Santos et al. (2009) and Freitas et al. (2011) obtained comparable results by demonstrating that there is a loss of water from eggs after laying and that the result of evaporation causes a progressive increase in the air chamber and, consequently, a decrease in the egg specific gravity. Furthermore, this reduction may be related to the loss of egg and albumen weight during storage.

Regarding colorimetry, there was an effect of storage time on the parameters $\mathrm{L}^{*}$ and $\mathrm{b}^{*}$ $(p<0.05)$. There was also a decrease in these measurements as the storage time of eggs increased, as Table 6 shows.

Table 6. Colorimetry $\left(\mathrm{L}^{*}, \mathrm{a}^{*}, \mathrm{~b}^{*}\right)$ of Japanese quail eggs fed on inclusions of algae calcareae and stored in four periods (zero, seven, 14, and 21 days)

\begin{tabular}{|c|c|c|c|c|c|c|c|c|c|c|}
\hline \multirow[b]{2}{*}{ Variable } & \multirow[b]{2}{*}{ Time } & \multicolumn{4}{|c|}{$\%$ of inclusion of calcareous seaweed } & \multirow[b]{2}{*}{ Mean } & \multirow[b]{2}{*}{ MSE } & \multicolumn{3}{|c|}{ Probability } \\
\hline & & 0 & 10 & 20 & 30 & & & $\mathrm{~N}$ & $\begin{array}{l}\text { Time } \\
(\mathrm{T})\end{array}$ & $\mathrm{N} * \mathrm{~T}$ \\
\hline $\mathrm{L}^{*}$ & 0 & 55.025 & 56.188 & 58.717 & 59.024 & $54.39 \mathrm{~A}$ & 1.566 & 0.248 & 0.0023 & 0.1201 \\
\hline
\end{tabular}




\begin{tabular}{|c|c|c|c|c|c|c|c|c|c|c|}
\hline & 7 & 54.221 & 54.695 & 43.160 & 50.143 & $54.84 \mathrm{~A}$ & & & & \\
\hline & 14 & 54.222 & 54.070 & 49.532 & 56.442 & $48.43 \mathrm{~B}$ & & & & \\
\hline & 21 & 54.092 & 54.407 & 42.321 & 59.858 & $46.36 \mathrm{~B}$ & & & & \\
\hline & Mean & 57.238 & 50.555 & 53.566 & 52.670 & & & & & \\
\hline \multirow{5}{*}{$a^{*}$} & 0 & -1.920 & -1.888 & -0.988 & -0.955 & -1.808 & \multirow{4}{*}{0.127} & \multirow{4}{*}{0.255} & \multirow{4}{*}{0.298} & \multirow{4}{*}{0.393} \\
\hline & 7 & -1.591 & -1.585 & -1.103 & -1.975 & -1.918 & & & & \\
\hline & 14 & -1.861 & -1.842 & -1.251 & -1.927 & -1.229 & & & & \\
\hline & 21 & -1.860 & -2.359 & -1.573 & -2.836 & -1.923 & & & & \\
\hline & Mean & -1.438 & -1.563 & -1.720 & -2.157 & & & & & \\
\hline \multirow{5}{*}{$b^{*}$} & 0 & 41.845 & 42.623 & 49.200 & 52.712 & $40.72 \mathrm{~A}$ & \multirow{4}{*}{1.372} & \multirow{4}{*}{0.589} & \multirow{4}{*}{0.0008} & \multirow{4}{*}{0.2393} \\
\hline & 7 & 40.403 & 38.468 & 35.134 & 42.330 & $40.45 \mathrm{~A}$ & & & & \\
\hline & 14 & 40.443 & 41.156 & 40.617 & 46.555 & 39.47 B & & & & \\
\hline & 21 & 40.623 & 41.156 & 32.943 & 45.313 & $36.72 \mathrm{~B}$ & & & & \\
\hline & Mean & 46.493 & 39.084 & 42.193 & 39.613 & & & & & \\
\hline
\end{tabular}

MSE: Mean standard error. Means followed by different letters in columns differ statistically by Tukey test at $5 \%$ significance.

Yolk color is an attribute resulting from the presence of carotenoids (carotenes and xanthophyll) present in the diet (VALENTIM et al., 2020). Therefore, the greater the consumption of foods rich in pigments, the more intense the yolk coloration. According to Moraleco et al. (2019), yolk color changes when eggs are stored at room temperature, corroborating the data of the present research. As storage time goes by, the water present in the albumen is transferred to the yolk, causing the carotenoid pigments to dilute in the medium, thus reducing the color reflection.

Egg quality is linked with characteristics that affect its acceptability by the consumer market. After laying, eggs lose quality continuously. It is an inevitable phenomenon

\section{CONCLUSION}

The inclusion of up to $30 \%$ of calcareous seaweed in replacement for calcite limestone in the diet of Japanese quails improves the weight and thickness of eggshells but does not influence the conservation of the eggs up to 21 days of storage. aggravated by several factors such as the nutritional and sanitary status of the laying hen, egg storage time, and temperature and relative humidity during storage (HENRIQUES et al., 2018).

Souza et al. (2015) concluded in their study that the inclusion of increasing levels of calcium in the feed is efficient to maintain the internal quality of Japanese quail eggs after storage at room temperature for 14 days, which was not verified in the present study.

Based on the results, the increase in shell thickness and weight with increasing inclusion of algae calcareae was not enough to improve the conservation of the internal quality of Japanese quail eggs.

\section{REFERENCES}

ALVARENGA, R. R., RODRIGUES, P. B., CANTARELLI, V. D. S., ZANGERONIMO, M. G., SILVA JÚNIOR, J. W. D., SILVA, L. R. D., ... \& PEREIRA, L. J. Energy values and chemical composition of Spirulina (Spirulina platensis) evaluated with 
broilers. Revista Brasileira de Zootecnia, v.40, n.5, p. 992-996, 2011.

ARAÚJO, A. L. A. C., DA SILVA MOREIRA, T., DE MENEZES, T. B. B., DE LIMA, R. L., DE MESQUITA FACUNDO, G., DA SILVA, J. W. A., ... \& COSTA, F. H. F. Use of Lithothamnium sp.(Algen ${ }^{\circledR}$ Oceana) in Penaeus vannamei culture/Uso do Lithothamnium sp.(Algen ${ }^{\circledR}$ Oceana) no cultivo de Penaeus vannamei. Brazilian Journal of Development, v. 6, n. 5, p. 28268-28283, 2020.

BARBOSA, N. A. A., SAKOMURA, N. K., MENDONÇA, M. D. O., FREITAS, E. R., \& FERNANDES, J. B. K. Qualidade de ovos comerciais provenientes de poedeiras comerciais armazenados sob diferentes tempos e condições de ambientes. Ars Veterinária, v.24, n.2, p.127-133, 2008

BITTENCOURT, T. M., LIMA, H. J. D. A., VALENTIM, J. K., MARTINS, A. C. D. S., MORALECO, D. D., \& VACCARO, B. C Distillers dried grains with solubles from corn in diet of japanese quails. Acta Scientiarum. Animal Sciences, v. 41, 2019.

CALDERANO, A. A. Fracionamento de dietas com níveis diferenciados de cálcio e fósforo para aves de postura. Rev. Eletrônica Nutritime, v. 7, n. 5, p. 13461352, 2010.

CASTELlÓ, J.A.L., PONTES, M.. GONZÁLEZ, F.F.1989. Producción de huevos. 1 ed. Barcelona, España. 367p. Real Escuela de Avicultura.

CARVALHO, F.B.C.; STRINGHINI, J.H.; JARDIM FILHO, R.M.; LEANDRO M.S.N.; PÁDUA. J.T.; DEUS, H.A.S.B. Influência da conservação e do período de armazenamento sobre a qualidade interna e de casca de ovos comerciais. Revista Brasileira de Ciência Avícola, v.18, p.100, 2003. Supl. 5.

CARVALHO, L. S. S., VILELA, D. R., FAGUNDES, N. S.,SOUZA, Y. L. S., \&FERNANDES, E. D. A. (2016). Qualidade de ovos e desempenho produtivo de poedeiras em segundo ciclo de postura alimentadas com microminerais quelatados a aminoácidos. Ciência Animal Brasileira, v. 17, n. 4, p. 491-500, 2016.

DIAS, G. T. Granulados bioclásticos: algas calcárias. Revista Brasileira de Geofísica, v. 18, n. 3, p. 307-318, 2000.

FERNANDEZ, I. B., CALIXTO, L. F. L., TORRES-CORDIDO, K. A. A., LEMOS, M. J. D., TOGASHI, C. K., SOUZA, D. S. D., ... \& PIZZOLANTE, C. C. Feeding time under performance and eggs quality of quails in production. Revista Brasileira de Saúde e Produção Animal, v. 19, n. 1, p. 136-143, 2018.

FERRONATO, C., BITTENCOURT, T. M., LIMA, H. J. D., VALENTIM, J. K., MARTINS, A. C. S., \& SILVA, N. E. M. Farelo de algodão na dieta de codornas japonesas. Boletim De Indústria Animal, v. 77, p. 1-8, 2020.

FREITAS, L. W., PAZ, I. C. D. L. A., GARCIA, R. G., CALDARA, F. R., DE OLIVEIRA SENO, L., FELIX, G. A., ... \& CAVICHIOLO, F. Aspectos qualitativos de ovos comerciais submetidos a diferentes condições de armazenamento. Revista Agrarian, v. 4, n. 11, p. 66-72, 2011.

HENRIQUES, S. J. K., RODRIGUES, R. B., \& UCZAY, M. Qualidade de ovos 
comerciais submetidos a diferentes condições de armazenamento. Revista Brasileira de Higiene e Sanidade Animal, v. 12, n. 2, p. 179-189, 2018.

LANA, S. R. V., LANA, G. R. Q., SALVADOR, E. D. L., LANA, Â. M. Q., CUNHA, F. S. A., \& MARINHO, A. L. Qualidade de ovos de poedeiras comerciais armazenados em diferentes temperaturas e períodos de estocagem. Revista Brasileira de Saúde e Produção Animal, v. 18, n. 1, p. 140-151, 2017.

LEMOS, M. D., CALIXTO, L. F., SOUZA, D., TORRES, K. A., REIS, T., COELHO, L., \& A FILHO, C. Efeito de diferentes aditivos zootécnicos sobre a qualidade de ovos em duas fases produtivas da codorna. Arquivo Brasileiro de Medicina Veterinária e Zootecnia, v. 69, n. 3, p. 751-760, 2017.

MELO, T. V., \& MOURA, M. A. Utilização da farinha de algas calcáreas na alimentação animal. Archivos de Zootecnia, v. 58, n. 224, p. 99-107, 2009.

MORALECO, D. D., VALENTIM, J. K., SILVA, L. G., LIMA, H. J. D. Á., BITENCOURTT, T. M., \& DALLAGO, G. M. Egg quality of laying hens fed diets with plant extracts. Acta Scientiarum. Animal Sciences, v. 41, 2019.

MOURA, G. R. S., REIS, R. D. S., MENDONÇA, M. D. O., SALGADO, H. R., ABREU, K. D. S., MADELLA, G. D. S., \& LIMA, M. B. D. Substitution of limestone for eggshell powder in the diet of Japanese laying quails. Revista Brasileira de Saúde e Produção Animal, v. 21, 2020.

ROSTAGNO, H. S.; ALBINO, L. F. T.; DONZELE, J. L. Tabelas brasileiras para aves e suínos: composição de alimentos e exigências nutricionais de aves e suínos. $3^{\mathrm{a}}$ edição, Viçosa, MG: UFV, 252 p., 2011.
SANTOS, M. D. S. V., ESPÍNDOLA, G. B., LÔBO, R. N. B., FREITAS, E. R., GUERRA, J. L. L., \& SANTOS, A. B. E. Efeito da temperatura e estocagem em ovos. Ciência e Tecnologia de Alimentos, v.29, n.3, p.513-517. 2009.

SILVA, A. F., SGAVIOLI, S., DOMINGUES, C. H. F., \& GARCIA, R. G. Coturnicultura como alternativa para aumento de renda do pequeno produtor. Arquivo Brasileiro de Medicina Veterinária e Zootecnia, v. 70, n. 3, p. 913-920, 2018.

SILVA, S. M., KAWAMURA, P. E., CUADROS, M. L., LEITE, B. G. D. S., DIAS, M. T., ROQUE, F. D. A., ... \& ARAÚJO, C. S. D. S. Efeitos da utilização da farinha de alga calcárea sobre 0 desempenho e a qualidade de ovos de poedeiras comerciais. Novos desafios da pesquisa em nutrição e produção animal. v.1, n1, p 1 -12, 2017.

SOUZA, D. S. D., SILVA FILHO, C. A., PINHO, T. P., AZEVEDO, V. M., OLIVEIRA, S. M., \& CALIXTO, L. F. L. Níveis de cálcio na manutenção da qualidade interna de ovos de codornas japonesas após armazenamento. Revista Brasileira de Saúde e Produção Animal, v. 16, n. 1, p. 139-148, 2015.

SAMLI, H.E.; AGMA, A.; SENKOYLU, N. Effects of Storage Time and Temperature on Egg Quality in Old Laying Hens. Journal of Applied Poultry Research, v.14, n.3, p.548-553, 2005.

SACCOMANI, A. P. O., MORAES, J. E., REIS, T. L., GANECO, A. G., THIMOTHEO, M., BORBA, H., ... \& PIZZOLANTE, C. C. Indicadores da qualidade fisico-química de ovos de 
poedeiras semipesadas criadas em diferentes sistemas de produção. Boletim De Indústria Animal, v. 76, p. 1-15, 2019.

VALENTIM, J. K., BITTENCOURT, T. M., LIMA, H. J. D. Á., TOSSUÉ, F. J. M., LOPES, Y. G., \& DA COSTA BRAGA, J. D. Alimentos alternativos como indutor de muda forçada em codornas poedeiras. Revista Acadêmica Ciência Animal, v. 17, p. 1-7, 2019.

VALENTIM, J. K., BITTENCOURT, T. M., LIMA, H. J. D. À., BARROS, F. K. Q., PEREIRA, I. D. B., ALMEIDA, G. R. D., \& ZIEMNICZAK, H. M.Natural and synthetic pigments in diet of Japanese quails. Acta Scientiarum. Animal Sciences, v. 42, 2020. 